\section{NEW YORK ACADEMY OF MEDICINE}

\section{CENTENARY AWARDS}

$\mathrm{T}$ HE end of the centenary celebration of the New York Academy of Medicine (see Nature, April 12, p. 494) was marked by a Convocation Meeting held on April 24. The Medal of the Academy was awarded to Dr. James Alexander Miller, an authority on tuberculosis, who has been associated with the Academy for many years and in 1937 was its president. This medal was established in 1930 by Dr. Samuel McCullagh, to be awarded periodically to a distinguished medical scientist in recognition of outstanding service to humanity.

The following were elected honorary fellows of the Academy :

Dr. J. B. Collip, director of the Research Institute of Endocrinology of McGill University, known for his work on blood and tissue chemistry, who was largely responsible for the chemical isolation of insulin; Dr. Robert Debré, professor in the Paris Faculty of Medicine, author of outstanding works in the field of pediatrics and public health; Sir John Fraser, principal of the University of Edinburgh and regius professor of clinical surgery in the University ; Dr. E. W. Goodpasture, professor of pathology and dean of the School of Medicine, Vanderbilt University, who has done outstanding work on virus diseases; Dr. Evert Gorter, professor of pediatrics, University of Ghent, known for his publications on the diseases of children; Prof. Einar Hammarsten, professor of pharmacology, Karolinska Institutet, Stockholm; Dr. A. V. Hill, Foulerton research professor of the Royal Society; Dr. G. M. Holmes, consulting physician to the National Hospital of Nervous Diseases, and president of the second International Neurological Congress; Dr. B. A. Houssay, president of the Argentine Society of Biology and of the Biological Section of the Argentine National Academy of Medicine, who has made valuable contributions to our knowledge of the hypophysis and pancreatic secretion; Sir William Wilson Jameson, chief medical officer of the Ministry of Health and Ministry of Education; Dr. Otto Loewi, known for work in the field of nerve physiology and on the chemical transmission of nerve impulses ; Dr. T. Madsen, formerly director of the Laboratory of the State Serum Institute in Denmark, known for outstanding work on serology and epidemiology and public health; Dr. M. Martinez-Báez, head of the Institute of Tropical Diseases and professor in the School of Hygiene, National University of Mexico; Dr. L. A. Orbeli, director of the Pavlov Institute in Leningrad, known for his work on the physiology of the nervous system; Sir John Boyd Orr, director-general of the United Nations Food and Agriculture Organisation; Dr. A. N. Richards, chairman of the Committee on Medical Research, Office of Scientific Research and Development, whose work in recent years has dealt with the function of the kidney; Prof. J. A. Ryle, professor of social medicine and head of the Institute of Social Medicine, University of Oxford ; Dr. René Sand, professor of social medicine, University of Brussels; Dr. H. E. Sigerist, director of the Institute of the History of Medicine, Johns Hopkins University, known for his work on the history of medicine; Dr. A. Stampar, rector and professor of public health and social medicine, University of Zagreb; Dr. A.
Tiselius, professor of biochemistry, University of Uppsala, who has made outstanding contributions to our knowledge of biologically important substances, and their separation through the development of an apparatus for electrophoresis.

The following were elected corresponding fellows of the Academy :

Dr. C. H. Best, professor of physiology, University of Toronto, co-discoverer of insulin; Dr. E. BraunMenéndez, physiologist connected with the Institute of Biology and Experimental Medicine in Buenos Aires; Dr. E. B. Chain, lecturer in chemical pathology, University of Oxford; Prof. H. R. Dean, professor of pathology, University of Cambridge; Dr. N. Hamilton Fairley, director of special research, Hospital for Tropical Diseases, London; Sir Alexander Fleming, professor of bacteriology, University of London, known for his work on bacteriology, immunology and chemotherapy, and on penicillin; Sir Howard Florey, professor of pathology, University of Oxford, known for his work on penicillin ; Dr. C. Heymans, professor of pharmacology and director of the Institute of Pharmacology and Therapeutics of the University of Ghent, who has worked on the physiology and pharmacology of the cardiovascular and central and peripheral systems and of respiration; Dr. A. Lacassagne, associate director, Pasteur Laboratory, Institute of Radium, University of Paris ; Dr. G. Liljestrand, professor of pharmacology and director of the Pharmacological Institute, Karolinska Institutet, Stockholm, known for his work on the physiology and pharmacology of respiration and the circulation; Dr. J. M. Mackintosh, dean and professor of public health, London School of Hygiene and Tropical Medicine, University of London; Dr. F. de P. Miranda, director of the National Institute of Nutrition of the Ministry of Public Health and Assistance, Mexico ; Dr. A. L. v. Muralt, professor of physiology and director of the Hallerianum, University of Bern; Dr. J. V. J. Parisot, professor of hygiene and social medicine and director of the Regional Institute of Hygiene, Nancy ; Dr. M. RuizCastañeda, director of the Department of Medical Research, General Hospital, Mexico City, known for his work on typhus and Malta fever; Dr. A. v. Szent-Györgyi, director of the Institute of Biochemistry, University of Budapest; Sir Lionel Whitby, regius professor of physic, University of Cambridge, known for work on hæmatological and bacteriological subjects.

Awards were made as follows :

Bowen-Brooks Scholarships (eight awards of 500 dollars each). Because of changing conditions, they are being given for continued study in the United States of returning young medical men : William Henry, Joseph F. Hindman, Martin H. Orens, Maurice S. Raben, E. Lawrence Reichel, C. R. Southworth, Stanley Stellar, Joseph R. Wilder.

Louis Livingston Seaman Award, for aid in investigation in bacteriology or sanitary science: Dr. James M. Neill, Cornell University Medical College (1,000 dollars); Dr. Arnold W. Pratt, Cornell University Medical College (500 dollars); Dr. A. M. Pappenheimer, New York University College of Medicine (500 dollars); Dr. Samuel Prigal, New York City (500 dollars).

Edward N. Gibbs Memorial Prize, given by Mrs. Gibbs and Mrs. Charles Sherrill (daughter): Dr. Stanley E. Bradley, College of Physicians and Surgeons (1,500 dollars). 